\title{
Molecular structure, chemical and nutrient profiles, and metabolic characteristics of the proteins and energy in new cool-season corn varieties harvested as fresh forage for dairy cattle
}

\author{
Saman Abeysekara, ${ }^{*}$ David A. Christensen, ${ }^{*}$ Zhiyuan Niu, ${ }^{*}$ Katerina Theodoridou, ${ }^{*}$ and Peiqiang $\mathrm{Yu}^{*} \dagger^{1}$ \\ *Department of Animal and Poultry Science, College of Agricultural and Bioresources, University of Saskatchewan, Saskatoon, SK, \\ S7N 5A8 Canada \\ †Tianjin Agricultural University, No. 22 Jinjin Road, Xiqing District, Tianjin 300384, China
}

\begin{abstract}
To our knowledge, no previous research exists concerning the molecular structure and metabolic characteristics of the proteins and energy that new cool-season corn varieties provide for dairy cattle. The objectives of this study were to identify the differences in the molecular structures of proteins among several new coolseason corn varieties [Pioneer P7443R, Pioneer P7213R, Pioneer P7535R (Pioneer Hi-Bred International Inc., Johnston, IA), Hyland Baxxos RR, Hyland SR22, and Hyland SR06 (Hyland Seeds, Blenheim, ON, Canada)] using Fourier transform infrared attenuated total reflectance (FT/IR-ATR) molecular spectroscopy, and to determine the nutrient profile and supply that each variety provided for dairy cattle. The protein molecular structure studies showed that the amide I to amide II ratio ranged from 1.09 to 1.66 and that the $\alpha$-helix to $\beta$-sheet ratio ranged from 0.95 to 1.01 among the new cool-season corn varieties. Energy content was significantly different among the new varieties. We found significant differences in the protein and carbohydrate subfractions and in the ruminal degradation kinetics of the organic matter, crude protein, starch, and neutral detergent fiber of the new varieties. The new varieties had similar estimated intestinal digestibilities for rumen undegraded crude protein. However, the new varieties had significant differences in predicted total truly absorbable protein, ranging from 39 to $57 \mathrm{~g} / \mathrm{kg}$ of dry matter, indicating that these newly developed varieties are satisfactory sources of truly absorbed protein for dairy cattle. Further study on the molecular structure profiles of cool-season corn in relation to its nutrient utilization and availability in dairy cattle is necessary. Key words: forage, protein molecular structure, metabolic characteristics, energy
\end{abstract}

\footnotetext{
Received March 21, 2013.

Accepted June 28, 2013.

${ }^{1}$ Corresponding author: peiqiang.yu@usask.ca
}

\section{INTRODUCTION}

Corn is a crop with a long history as a foodstuff for both animals and humans (Lauer et al., 2001; Arturo, 2003 ), and $40 \%$ of current global corn production is used as animal feed (Gyori, 2010). Canada harvests over 190,000 ha of corn forage, with the highest production being in Ontario (63\%) and the second highest $(21 \%)$ in the province of Quebec (Coors and Lauer, 2001).

The corn grown in the Canadian prairies is different from the corn varieties grown in warmer climates (Lassiter et al., 1958). The main differences are due to the shorter growing season and lower growing temperatures in the Canadian prairies compared with the areas of warm-season corn production, such as the United States (Lauer et al., 2001). The differences among varieties include changes in chemical profile and the nutrient composition of silage (Mahanna, 2010).

In corn cultivation, crop heat units (CHU) are calculated from daytime temperatures above $10^{\circ} \mathrm{C}$ and nighttime temperatures above $4.4^{\circ} \mathrm{C}$ on a cumulative daily basis from seeding to harvest. Many corn varieties for western Canada require $\geq 2,000 \mathrm{CHU}$ to reach the silage harvest stage, with a kernel maturity of $45 \%$ DM.

Recently, 6 cool-season corn varieties have been developed: Pioneer P7443R, Pioneer P7213R, Pioneer P7535R (Pioneer Hi-Bred International Inc., Johnston, IA), Hyland Baxxos RR, Hyland SR22, and Hyland SR06 (Hyland Seeds, Blenheim, ON, Canada). However, no systematic research has been conducted on the molecular structure, chemical and nutrient profiles, and metabolic characteristics of the protein and energy of these newly developed cool-season corn varieties.

Fourier transform infrared attenuated total reflectance (FT/IR-ATR) molecular spectroscopy is able to detect molecular structural features in biological materials, as well as processing-induced structural changes (Doiron et al., 2009; Liu and Yu, 2010). The hypotheses of this study were that (1) the differences in the molecular structures of the proteins among the new cool-season corn varieties could be detected by 
molecular spectroscopy, (2) the magnitude of the differences among these new cool-season corn varieties was significant, and (3) the chemical and nutrient profiles of the newly developed cool-season corn varieties significantly differ from those of corn varieties grown in warm climates.

The objectives of this study were (1) to identify differences in the molecular structures of proteins among the new cool-season corn varieties using FT/IR-ATR molecular spectroscopy; (2) to investigate the differences in chemical profile, as well as the protein and carbohydrate subfractions, among the cool-season corn varieties; (3) to determine the ruminal degradation kinetics of various nutrients among the cool-season corn varieties; (4) to predict the intestinal availability of protein among the cool-season corn varieties; and (5) to reveal the metabolic characteristics of the proteins and model the amount of truly absorbable protein in the small intestine.

\section{MATERIALS AND METHODS}

\section{Corn Cultivation, Experimental Design, and Sampling}

Six new cool-season corn varieties were grown at the Canada-Saskatchewan Irrigation Diversification Centre (Outlook, SK, Canada) from May to September 2011. The varieties included Pioneer 7443R, Pioneer 7213R, Pioneer 7535R, Hyland Baxxos RR, Hyland SR22, and Hyland SR06. The experimental design was a randomized completed block design. The cultivation was designed with 4 replicates (4 fields or blocks) with a total of 24 plots for the 6 varieties. Seeding was performed on May 20, 2011, and harvesting (and sampling) was performed on September 29, 2011, after 2,160 CHU had been reached.

\section{Molecular Spectroscopy}

The molecular spectral data of the corn samples were collected and corrected for the background spectrum using FT/IR molecular spectroscopy (Jasco 4200, Jasco International Co. Ltd., Tokyo, Japan). The spectra were generated for the mid-infrared region (approximately 4,000-800 $\mathrm{cm}^{-1}$ ) and the fingerprint region (approximately $1,800-800 \mathrm{~cm}^{-1}$ ) with a spectral resolution of 4 $\mathrm{cm}^{-1}$. The FT/IR spectral data were processed using Omnic 7.3 (Spectra-Tech, Madison, WI). The regions of specific interest in this study included the protein amide I and II and the protein structure of the $\alpha$-helix and $\beta$-sheet in the infrared regions of approximately 1,715-1,480 $\mathrm{cm}^{-1}$ (Samadi and $\mathrm{Yu}, 2011$; Liu et al., 2012).

\section{Univariate Spectral Analysis}

The protein molecular structure spectral profile was determined from the 2 primary bands in the spectra; namely, the amide I and amide II regions (Yu, 2010; Khan and $\mathrm{Yu}, 2013)$. The amide I and amide II peak area absorption intensities and their ratios were calculated. Using the second-derivative functions in Omnic 7.3, the amide I peak was further resolved into several multi-component peaks in which $\alpha$-helices (centered at $\sim 1,655 \mathrm{~cm}^{-1}$ ) and $\beta$-sheets (centered at $\sim 1,630 \mathrm{~cm}^{-1}$ ) were identified. The intensities of the peak heights for the $\alpha$-helix and $\beta$-sheet were calculated.

\section{Rumen Degradation Procedures}

The rumen in situ degradation parameters were determined using the method described previously ( $\mathrm{Yu}$ et al., 2002). Fresh forage samples were chopped to 1 $\mathrm{cm}$ in size, dried at $55^{\circ} \mathrm{C}$ for $72 \mathrm{~h}$ and ground through a Christy \& Norris 10-inch feed mill (Christy Turner Ltd., Suffolk, UK) using a 2-mm screen. Approximately 7 to $9 \mathrm{~g}$ of each dried forage sample was weighed into a nylon bag (Nitex 03-41/31 monofilament open mesh fabric, Screentec Corp., Mississauga, ON, Canada) with dimensions of $10 \times 20 \mathrm{~cm}$ and a pore size of $41 \mu \mathrm{m}$. The ratio of the sample size to the bag surface area averaged $\sim 17.5 \mathrm{mg} / \mathrm{cm}^{-2}$, similar to that used in previous work (Ørskov and McDonald, 1979; Nocek and Tamminga, 1991). A polyester mesh bag $(45 \times 45 \mathrm{~cm}$ with a $90-\mathrm{cm}$ length of nylon rope for anchoring to the cannula) was used to hold the sample bags in the rumen. The sample bags were added to the polyester mesh bag according to a gradual addition-all out schedule and incubated for $72,48,24,12,6,2$, and $0 \mathrm{~h}$. The number of bags incubated for each sample was determined according to the previous work (Bal et al., 2000; Jurjanz and Monteils, 2005; Zanton and Heinrichs, 2009). The maximum number of bags in the rumen at any one time was 30 based on previous effective degradability data (Huntington and Givens, 1995). All samples were incubated for 2 runs in 3 nonlactating Friesian cows fitted with rumen cannula and fed $570 \mathrm{~g} / \mathrm{kg}$ of barley silage, $100 \mathrm{~g} /$ $\mathrm{kg}$ of alfalfa hay, $50 \mathrm{~g} / \mathrm{kg}$ of dehydrated alfalfa pellets, and $280 \mathrm{~g} / \mathrm{kg}$ of concentrates (containing barley, wheat, oats, canola meal, soybean meal, wheat distillers dried grains with solubles, corn gluten meal, molasses, golden flakes, canola oil, minerals, and vitamins). After incubation, the bags were removed from the rumen and, together with those samples representing $0 \mathrm{~h}$, rinsed under cold water to remove excess ruminal contents. The samples were then washed with cool water and dried at $55^{\circ} \mathrm{C}$ for $48 \mathrm{~h}$. The dry samples were stored at $4^{\circ} \mathrm{C}$ until further analysis. 


\section{Chemical Analyses}

The dried forage samples and ruminal residue samples were further ground through a 1-mm screen (Retsch ZM-1, Brinkmann Instruments Canada Ltd., Mississauga, ON, Canada) for use in chemical analyses. Dry matter (method 930.15), ash (method 942.05), crude fat (method 954.02), and CP (method 984.13) contents were analyzed according to the AOAC (1990) procedures. Starch content was analyzed using the Megazyme Total Starch Assay Kit (Megazyme, Co. Bray, Ireland) and the $\alpha$-amylase/amyloglucosidase method (McCleary et al., 1997). The ADF, NDF, and ADL values were also analyzed (Van Soest et al., 1991). Amylase and sulfite were not used for ADF and ADL. For NDF, amylase was used, but sulfite was not, because the NDF residues were analyzed for neutral detergent insoluble CP (NDICP). The NPN content was analyzed by precipitating the true protein with tungstic acid (Licitra et al., 1996). The total soluble CP (SCP) was analyzed by incubating the sample with a bicarbonate-phosphate buffer and filtering it through Whatman 54 filter paper. The ADIN and NDIN values were also measured (Licitra et al., 1996). The NSC contents, including sugars, organic acids, and other reserve carbohydrates, were estimated using NFC and calculated (NRC, 2001).

\section{Energy Estimate}

The estimated energy for the total digestible $\mathrm{CP}$ (tdCP), fatty acids (tdFA), NDF (tdNDF), NFC $($ tdNFC), total digestible nutrients at $1 \times$ maintenance $\left(\mathbf{T D N} \mathbf{1}_{1 \times}\right)$, digestible energy $(\mathbf{D E})$ at the production level of intake $\left(\mathbf{D E}_{3 \times}\right)$, ME at the production level of intake $\left(\mathbf{M E}_{3 \times}\right)$ and $\mathrm{NE}_{\mathrm{L}}$ at the production level of intake $\left(\mathbf{N E L}_{3 \times}\right)$ were determined using a summative approach (Weiss et al., 1992) from NRC (2001), whereas $\mathrm{NE}_{\mathrm{M}}$ and $\mathrm{NE}_{\mathrm{G}}$ were estimated using $\mathrm{NRC}$ (1996). Both the NRC (2001; dairy) and NRC (1996; beef) use the same formula to estimate $\mathrm{NE}_{\mathrm{M}}$ and $\mathrm{NE}_{\mathrm{G}}$.

\section{Cornell Net Carbohydrate and Protein System}

The $\mathrm{CP}$ and carbohydrate (CHO) subfractions were partitioned according to the Cornell Net Carbohydrate and Protein System (CNCPS, version 6.1; Sniffen et al., 1992; Fox et al., 2004; Tylutki et al., 2008). The characterization of the carbohydrate fractions applied in this system is CA (CA1, CA2, CA3, and CA4), $\mathrm{CB}$ (CB1, CB2 and CB3), and CC (Fox et al., 2004; Tylutki et al., 2008).
The characterization of the CP fractions is as follows: fraction PA is NPN, fraction PB is true protein (TP), and fraction $\mathrm{PC}$ is unavailable protein. Fraction $\mathrm{PB}$ is further divided into 3 fractions (PB1, PB2, and PB3). The buffer-insoluble protein minus fraction PB3 is used to estimate fraction PB2. Fraction PB2 is insoluble in buffer but soluble in neutral detergent, whereas fraction PB3 is insoluble in both buffer and neutral detergent but is soluble in acid detergent solution. Fraction PB2 is fermented in the rumen at a lower rate than the buffer-soluble fraction, and some of PB2 fraction escapes to the lower gut. Fraction PB3 is believed to be more slowly degraded in the rumen than fractions PB1 and PB2 because of its association with the plant cell walls; a large proportion of PB3 is thus believed to escape the rumen. Fraction PC is ADIN, which is highly resistant to breakdown by microbial and mammalian enzymes; it is assumed to be unavailable to animal digestion (Fox et al., 2004; Tylutki et al., 2008).

\section{Rumen Degradation Model for In Situ Study}

The first-order kinetic degradation model described by Ørskov and McDonald (1979), with several modifications (Robinson et al., 1986; Dhanoa, 1988), was applied to describe the rumen degradation characteristics of DM, OM, CP, starch, and NDF. The model was solved with the NLIN procedure of SAS (SAS Institute Inc., Cary, NC) via iterative least squares regression (Gauss-Newton method) using the following equation:

$$
\mathrm{R}(\mathrm{t})=\mathrm{U}+(100-\mathrm{S}-\mathrm{U}) \times \exp ^{-\mathrm{K}_{\mathrm{d}} \times\left(\mathrm{t}-\mathrm{T}_{0}\right)},
$$

where $\mathrm{R}(\mathrm{t})=$ residue present $(\%)$ at $\mathrm{t}$ hours of incubation; $\mathbf{U}=$ undegradable fraction (\%); $\mathbf{S}=$ soluble fraction (\%); $\mathbf{K}_{\mathbf{d}}=$ degradation rate $(\% / \mathrm{h})$; and $\mathbf{T}_{\mathbf{0}}=$ lag time (h).

Based on the parameters $\mathrm{S}, \mathrm{U}, \mathrm{D}$, and $\mathrm{K}_{\mathrm{d}}$, the rumenundegraded feed $\mathrm{CP}$ and rumen-undegraded starch (RUSt) contents were predicted by the following equations:

$$
\begin{gathered}
\operatorname{RUP}(\%)=\mathrm{U}+\left(\mathrm{D} \times \mathrm{K}_{\mathrm{p}}\right) /\left(\mathrm{K}_{\mathrm{p}}+\mathrm{K}_{\mathrm{d}}\right) \\
\text { and RUSt }(\%)=\mathrm{S} \times 0.1+\left(\mathrm{D} \times \mathrm{K}_{\mathrm{p}}\right) /\left(\mathrm{K}_{\mathrm{p}}+\mathrm{K}_{\mathrm{d}}\right),
\end{gathered}
$$

where $\mathrm{D}=100-\mathrm{S}-\mathrm{U}(\%)$, and $\mathrm{K}_{\mathrm{p}}$ is the estimated rate of digesta outflow from the rumen $(\% / \mathrm{h})$ and was assumed to be $6 \% / \mathrm{h}$, according to Tamminga et al. (1994). The value 0.1 is a compensation factor between the in situ and in vivo starch results, indicating that $10 \%$ of the $\mathrm{S}$ fraction of starch escapes rumen degrada- 
tion (Nocek and Tamminga, 1991; Tamminga et al., 1994; Yu et al., 2003).

\section{Metabolic Characteristics of the Proteins and Prediction of Nutrient Supply to Dairy Cattle}

The PDI system was applied to detect the magnitude of the differences among newly developed cool-season corn varieties (INRA, 2007). The protein value of the feeds and the animal requirements are both expressed in terms of true protein truly digestible in the small intestine, abbreviated as PDI. The PDI system was first proposed by Verité and Geay (1987), and it was used in this study to determine the PDI value for each individual feed. The PDI system aims to balance the nitrogen and energy available in the rumen for microbial protein synthesis and to provide a value for the feedstuffs reflective of the true protein absorbed in the small intestine. The PDI system requires the accurate measurement of the characteristics of feed protein degradation in the rumen and feed protein intestinal digestion.

The PDI content of a diet is the sum of 2 fractions: PDIA, the dietary protein undegraded in the rumen but truly digestible in the small intestine, and PDIM, the microbial true protein that is truly digestible in the small intestine. PDIMN indicates the amount of microbial protein that could be synthesized in the rumen from degraded dietary $\mathrm{N}$ when energy and other nutrients are not limiting. PDIME indicates the amount of microbial protein that could be synthesized from the energy available in the rumen when degraded $\mathrm{N}$ and other nutrients are not limiting. The value of each feed is given directly as the sum of PDIA and PDIM, and each of the 2 following possible situations is considered separately: PDIN $=$ PDIA + PDIMN, and PDIE $=$ PDIA + PDIME.

The PDI values were obtained from 4 individual feed characteristics: (1) CP content, (2) effective degradability of CP (EDCP) as measured by the rumen incubation procedure, (3) fermentable OM content (FOM) as calculated from the total digestible OM (DOM) content after the subtraction of the contents of the ether extract and the undegradable dietary protein in the feed and fermentation products in the silage, and (4) true intestinal digestibility of the rumen undegraded dietary true protein (TId).

\section{Prediction of Microbial Protein Synthesis in the Rumen Based on Available Energy or Ruminally Degraded Protein}

Microbial protein synthesis was predicted from FOM, or the amount of OM that could be fermented by the bacteria in the rumen (Verité and Geay, 1987; Tamminga et al., 1994; NRC, 2001). The FOM content corresponds to the product of the subtraction of the digestible fractions that are of low or no value for microbial energy metabolism, such as ether extract (EE) and those fractions previously unavailable in the rumen, from the DOM content. This value was calculated using the following formula: FOM $(\mathrm{g} / \mathrm{kg})=\mathrm{DOM}-\mathrm{EE}-$ $\mathrm{CP} \times(1-\mathrm{EDCP})$. The amount of microbial protein that could be synthesized from the energy available in the rumen was calculated with the formula

$$
\mathrm{PDIME}=\mathrm{FOM} \times 0.145 \times 0.8 \times 0.8,
$$

where the factor 0.145 represents the yield of microbial protein (assumed to be $145 \mathrm{~g}$ of $\mathrm{CP} / \mathrm{kg}$ of $\mathrm{FOM}$ with regard to energy substrates); the AA content of both microbial protein and true digestible protein in the small intestine are assumed to be constant and equal to 0.8 in the French PDI System (Verité and Geay, 1987).

The amount of microbial protein that could be synthesized in the rumen from the degraded dietary $\mathrm{N}$ was calculated using the following formula: PDIMN $=\mathrm{CP}$ $\times[1-1.11 \times(1-\mathrm{EDCP})] \times 0.9 \times 0.8 \times 0.8$, where 0.9 is the efficiency of the conversion of degraded $\mathrm{N}$ to rumen microbial $\mathrm{N}$.

\section{Prediction of Feed Protein Rumen Effective Degradability and Truly Absorbed Rumen Undegraded Feed Protein in the Small Intestine}

The effective degradability in the rumen of feed protein was estimated as follows:

$$
\begin{aligned}
\operatorname{EDCP}(\%)= & 51.2+0.14 \times \mathrm{CP}-0.00017 \\
& \times \mathrm{CP}^{2}+\Delta
\end{aligned}
$$

where $\Delta=-71$. The true digestibility in the intestine of rumen undegraded feed protein was calculated as follows:

$$
\begin{gathered}
\mathrm{TId}(\%)=100 \times[1.11 \times(1-\mathrm{EDCP} / 100) \\
\times \mathrm{CP}-\mathrm{PANDI}] /[1.11 \times(1-\mathrm{EDCP} / 100) \times \mathrm{CP}],
\end{gathered}
$$

where PANDI represents the quantity of rumen undegraded feed protein that was not digested in the small intestine. This value was calculated using the following formula:

$$
\begin{gathered}
\text { PANDI }=7.9+0.08 \times \mathrm{CP}-0.00033 \times \mathrm{CP}^{2} \\
+\Delta_{1}+\Delta_{2}+\Delta_{3},
\end{gathered}
$$


Table 1. Differences in protein molecular structure spectral profiles among cool-season corn forage varieties, based on Fourier transform infrared (IR) attenuated total reflectance molecular spectroscopy ${ }^{1}$

\begin{tabular}{|c|c|c|c|c|c|c|c|c|}
\hline \multirow[b]{2}{*}{ Item (IR absorption unit) } & \multicolumn{3}{|c|}{ Pioneer } & \multicolumn{3}{|c|}{ Hyland } & \multirow[b]{2}{*}{ SEM } & \multirow{2}{*}{$\begin{array}{c}\text { Contrast } \\
(P \text {-value }) \\
\text { Pioneer vs } \\
\text { Hyland }\end{array}$} \\
\hline & P7443R & P7213R & P7535R & Baxxos RR & SR22 & SR06 & & \\
\hline Amide I $\left(\sim 1,648 \mathrm{~cm}^{-1}\right)$ & 0.0175 & 0.0209 & 0.0172 & 0.0225 & 0.0154 & 0.0198 & 0.0011 & 0.50 \\
\hline Amide II $\left(\sim 1,540 \mathrm{~cm}^{-1}\right)$ & 0.0128 & 0.0154 & 0.0113 & 0.0187 & 0.0093 & 0.0182 & 0.0010 & 0.03 \\
\hline Ratio of amide I to II & 1.3730 & 1.3494 & 1.5574 & 1.2504 & 1.6785 & 1.0973 & 0.0306 & 0.05 \\
\hline$\alpha$-Helix $\left(\sim 1,656 \mathrm{~cm}^{-1}\right)$ & 0.0167 & 0.0197 & 0.0165 & 0.0205 & 0.0151 & 0.0190 & 0.0011 & 0.55 \\
\hline Ratio of $\alpha$-helix to $\beta$-sheet & 0.9868 & 0.9841 & 0.9586 & 1.0063 & 0.9507 & 0.9816 & 0.0084 & 0.69 \\
\hline
\end{tabular}

${ }^{1}$ Cultivation was designed with 4 replicates (4 fields as block effect) with an outcome of 24 plots from 6 varieties $(6$ varieties $\times 4$ blocks $=24$ samples). Corn varieties were from Pioneer Hi-Bred International Inc. (Johnston, IA) and Hyland Seeds (Blenheim, ON, Canada).

where $\Delta_{1}=-1.9, \Delta_{2}=-2.3$, and $\Delta_{3}=-2.0$.

The truly absorbed rumen undegraded feed protein in the small intestine (PDIA) was calculated using the following formula: PDIA $=\mathrm{CP} \times[1.11 \times(1-\mathrm{EDCP})]$ $\times$ TId, where the effective rumen bypass of protein is assumed to be $1.11 \times(1-\mathrm{EDCP})$ (French PDI system).

\section{Statistical Analysis}

The data from the chemical analyses, in situ assays, and model estimations were analyzed using the MIXED procedure of SAS (version 9.2, SAS Institute Inc., Cary, $\mathrm{NC}$ ). The model used for the analysis was as follows: $\mathrm{Y}_{\mathrm{ij}}$ $=\mu+F_{i}+e_{i j}$, where $Y_{i j}$ was an observation of the dependent variable ${ }_{\mathrm{ij}} ; \mu$ was the population mean for the variable; $F_{i}$ was the fixed effect of variety; fields (block) and in situ cow and runs were random effects; and $e_{i j}$ was the random error associated with the observation ${ }_{\mathrm{ij}}$.

To solve the first-order kinetic degradation model, the NLIN procedure of SAS with iterative least squares regression (Gauss-Newton method) was applied. For all statistical analyses, significance was declared at $P<$ 0.05 and significance trending at $P \leq 0.10$. The treatment means were compared using the Tukey-Kramer honestly significant difference (HSD) procedure.

\section{RESULTS AND DISCUSSION}

\section{Protein Structure Spectral Profiles}

Amide I and Amide II. Table 1 gives the protein molecular structure parameters for the cool-season corn forage varieties. Amide I and amide II intensity did not differ among the varieties. However, the amide I to amide II ratio exhibited significant differences, ranging from 1.09 to 1.66 (Table 1). These differences in the amide I to amide II ratio indicated different molecular structure compositions or conformations among the cool-season corn forage varieties, which may be related to nutrient availability

$\boldsymbol{\alpha}$-Helix and $\boldsymbol{\beta}$-Sheet. Table 1 shows the protein molecular structure characteristics in terms of the $\alpha$-helix and $\beta$-sheet peaks. The intensities of the $\alpha$-helix and $\beta$ sheet peak heights were not significantly different among the cool-season corn forage varieties. The $\alpha$-helix to $\beta$ sheet ratio ranged from 0.95 to 1.01 (Table 1). Again, the differences in the $\alpha$-helix to $\beta$ sheet ratios may indicate different protein molecular structure conformations among the cool-season corn forage varieties, which may be related to nutrient digestion. No previous work in corn could be found with which to compare our present results.

\section{Chemical Profiles of Fresh Forage}

The corn fresh forage chemical profiles are presented in Table 2. Hyland SR 22 had the lowest DM content $(424 \mathrm{~g} / \mathrm{kg})$ and Pioneer 7213R had the highest $(603 \mathrm{~g} /$ $\mathrm{kg})$. The DM content of whole corn plants has previously been reported as 320 to $400 \mathrm{~g} / \mathrm{kg}$ of DM (Bal et al., 2000; Jurjanz and Monteils, 2005), a value lower than our present findings. These differences may be attributable to the dry weather conditions of the prairies in which the experiment was conducted (Bal et al., 2000; Mahanna, 2010) or to the presampling time and procedure. The chemical profiles of the varieties were different on a DM basis. However, higher temperatures and greater light intensity have been shown to increase the DM content of whole corn plants (Struik et al., 1985). The Hyland varieties had significantly different values for $\mathrm{NDF}(\sim 500 \mathrm{~g} / \mathrm{kg}$ of DM), starch $(\sim 211 \mathrm{~g} / \mathrm{kg}$ of DM) and $\mathrm{CP}(\sim 74 \mathrm{~g} / \mathrm{kg}$ of DM) compared with the Pioneer varieties (NDF 489, starch 260, and CP $69 \mathrm{~g} /$ $\mathrm{kg}$ of DM). Both the NDF and ADF values were significantly lower $(P<0.05)$ in Hyland SR 22 compared 
Table 2. Differences in chemical and nutrient profiles: Comparison of the cool-season corn forage varieties ${ }^{1}$

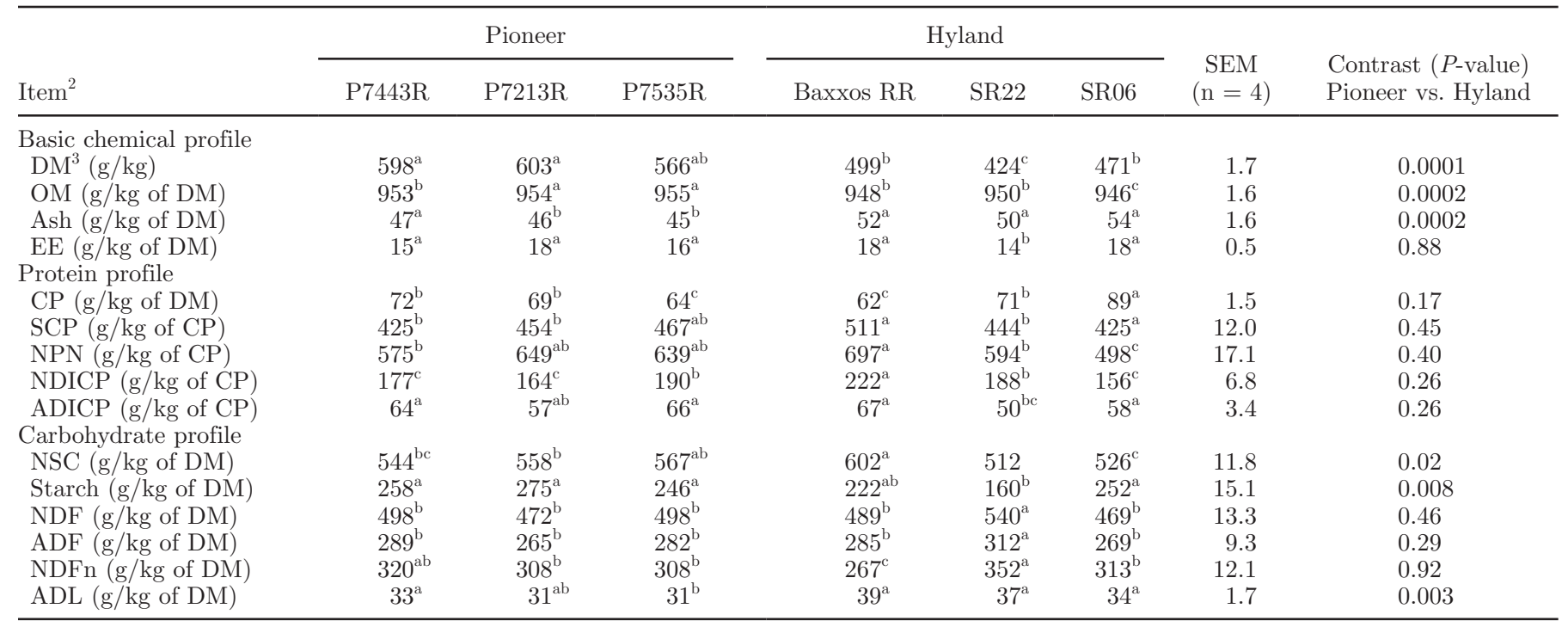

\footnotetext{
${ }^{\mathrm{a}-\mathrm{C}}$ Values in a row with different letters are statistically different at $P<0.05$ by Tukey comparison.

${ }^{1}$ Corn varieties were from Pioneer Hi-Bred International Inc. (Johnston, IA) and Hyland Seeds (Blenheim, ON, Canada).

${ }^{2} \mathrm{ADICP}=$ acid detergent insoluble $\mathrm{CP} ; \mathrm{CHO}=$ carbohydrate; $\mathrm{EE}=$ ether extract (crude fat); NDFn $=\mathrm{N}$-adjusted NDF, calculated as $\mathrm{NDFn}$ $=\mathrm{NDF}-\mathrm{NDICP} ; \mathrm{NDICP}=$ neutral detergent insoluble $\mathrm{CP} ; \mathrm{SCP}=$ soluble $\mathrm{CP}$.

${ }^{3}$ This DM is expressed on oven-dried and plant-based basis; moisture loss occurred from the point of sampling to analysis. These samples were harvested $1 \mathrm{~d}$ before being collected from the experimental station.
}

with the other varieties. Starch was higher in the Pioneer varieties, with the highest starch content $(275 \mathrm{~g} /$ $\mathrm{kg}$ of DM) observed for P7213R. In previous research, starch levels were $>300 \mathrm{~g} / \mathrm{kg}$ of DM in corn fresh forage (Johnson et al., 2003; Hallada et al., 2008; Mahanna, 2010), a value slightly higher than our present findings.

Crude protein compositions varied across the varieties, with the highest value $(90 \mathrm{~g} / \mathrm{kg}$ of DM) observed in Hyland SR06 (Table 2). Additionally, Hyland Baxxos RR had the highest SCP (511 g/kg of CP) and NPN $(697 \mathrm{~g} / \mathrm{kg}$ of $\mathrm{CP})$ values. These $\mathrm{CP}$ values were in agreement with those of previous work (Sniffen et al., 1992; Jurjanz and Monteils, 2005). The lowest lignin levels $(31 \mathrm{~g} / \mathrm{kg}$ of $\mathrm{DM})$ were found in Pioneer $7535 \mathrm{R}$ and 7213R (Table 1); however, these levels were higher than previously reported values (Jurjanz and Monteils, 2005). The presence of lignin may be reflected by a physical shielding against fiber digestion (Hatfield, 1989). Both the neutral and acid detergent insoluble crude protein (NDICP and ADICP) values were in agreement with previous results reported for corn forage (Sniffen et al., 1992). Nutrient values for whole corn plants (NDF 445, lignin 30, and starch $310 \mathrm{~g} /$ $\mathrm{kg}$ of DM) have been reported previously (Hunt et al., 1989; Coors and Lauer, 2001) and are in close agreement with our present results. Therefore, the nutrient concentrations of corn grown in cooler prairie climates were not inferior to those of warm-season corn. In the
NRC (2001) report, corn fresh forage is not listed; however, the nutrient compositions (NDF 45, CP 8.8, and EE $3.2 \%$ of DM) reported for corn silage (NRC, 2001) were in agreement with our findings (NDF 49, CP 7.1, and EE $1.7 \%$ of DM) for fresh forage. No starch data were listed for corn silage by the NRC (2001).

\section{Digestible Nutrients and Estimated Energy Values}

Total digestible nutrients $\left(\mathrm{TDN}_{1 \times}\right)$, $\mathrm{DE}, \mathrm{ME}$ for production, and NE (for lactation, maintenance, and weight gain) estimated using the NRC (2001) methods are presented in Table 3 . These values ranged from 65.5 to $68.4 \%$ of $\mathrm{DM}$ for $\mathrm{TDN}_{1 \times}, 2.79$ to $2.90 \mathrm{Mcal} / \mathrm{kg}$ of $\mathrm{DM}$ for $\mathrm{DE}_{3 \times}, 2.14$ to $2.24 \mathrm{Mcal} / \mathrm{kg}$ of $\mathrm{DM}$ for $\mathrm{ME}_{\mathrm{p} 3 \times}$, and 1.31 to $1.74 \mathrm{Mcal} / \mathrm{kg}$ of $\mathrm{DM}$ for $\mathrm{NE}_{\mathrm{Lp} 3 \times}$. Pioneer 7213R contained the highest energy values of the studied varieties, whereas Hyland SR22 had the lowest values (NRC, 2001). Truly digestible nutrients, such as NFC, NDF, CP, and FA, were used to estimate TDN and energy (Yu et al., 2003). The energy estimates were relatively similar between the Pioneer $(2.9,2.2$, and 1.4 Mcal/kg of $\mathrm{DM}$ for $\mathrm{DE}_{3 \times}, \mathrm{ME}_{3 \times}$, and $\mathrm{NEL}_{3 \times}$, respectively) and Hyland $(2.8,2.2$, and $1.5 \mathrm{Mcal} / \mathrm{kg}$ of DM for $\mathrm{DE}_{3 \times}, \mathrm{ME}_{3 \times}$, and $\mathrm{NEL}_{3 \times}$, respectively) varieties. These findings were in agreement with published values for regular corn silage $(68.8 \%, 2.9,2.3$, and $1.5 \mathrm{Mcal} / \mathrm{kg}$ for TDN, $\mathrm{DE}_{1 \times}, \mathrm{ME}_{3 \times}$, and $\mathrm{NEL}_{3 \times}$, respectively; NRC, 
Table 3. Differences in digestible nutrients and energy values determined using NRC-chemical summary approach: Comparison among the cool-season corn forage varieties ${ }^{1}$

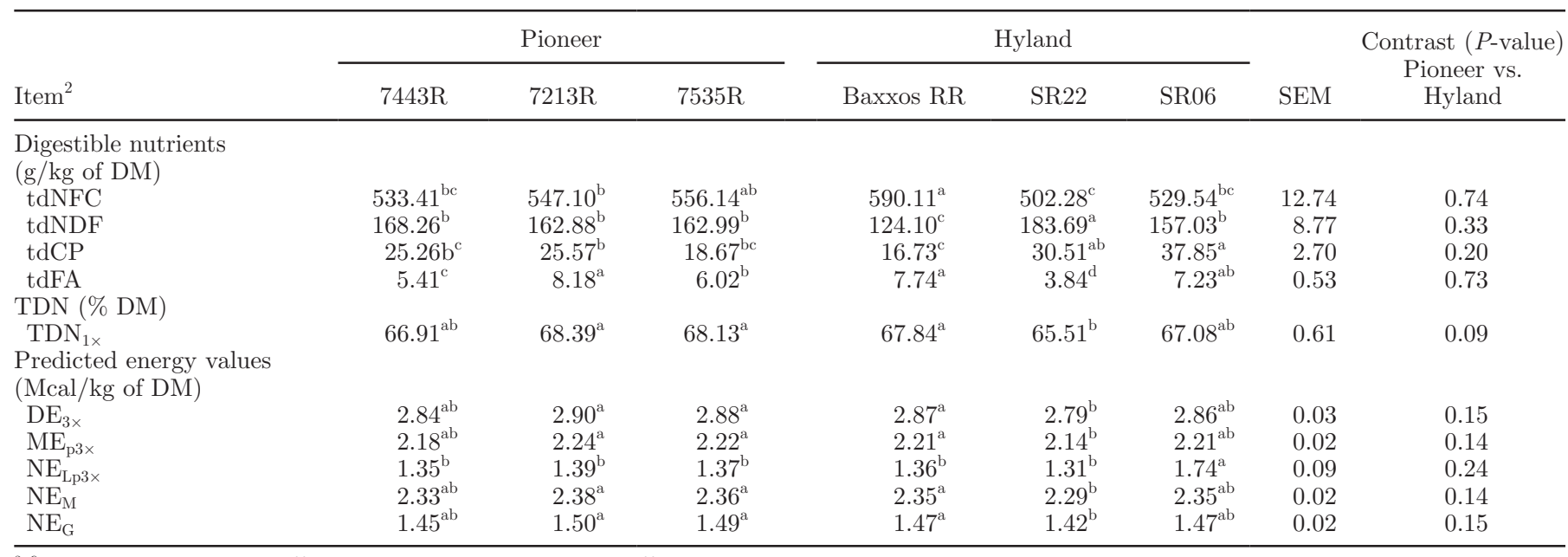

${ }^{a-c}$ Values in a row with different letters are statistically different at $P<0.05$ by Tukey comparison.

${ }^{1}$ Corn varieties were from Pioneer Hi-Bred International Inc. (Johnston, IA) and Hyland Seeds (Blenheim, ON, Canada).

${ }^{2}$ tdNFC $=$ truly digestible $\mathrm{NFC} ;$ tdNDF $=$ truly digestible $\mathrm{NDF} ; \mathrm{tdCP}=$ truly digestible $\mathrm{CP} ; \mathrm{tdFA}=$ truly digestible $\mathrm{FA}$; $\mathrm{TDN}_{1 \times}=$ total digestible nutrient at $1 \times$ maintenance; $\mathrm{DE}_{3 \times}=$ digestible energy at production level of intake $(3 \times) ; \mathrm{ME}_{3 \times}=\mathrm{ME}$ at production level of intake $(3 \times)$; $\mathrm{NE}_{\mathrm{L} 3 \times}=\mathrm{NE}_{\mathrm{L}}$ at production level of intake $(3 \times)$.

2001). Therefore, these cooler climate varieties provided adequate energy and digestible nutrients for ensiling or for the direct feeding of ruminants as fresh forage.

\section{Estimated Carbohydrate and Protein Fractions}

Total carbohydrate levels in the corn fresh forage were found to be $>800 \mathrm{~g} / \mathrm{kg}$ of DM (Table 2). The carbohydrate pool of the Pioneer varieties was higher $(868 \mathrm{~g} / \mathrm{kg}$ of DM; $P=0.02)$ than that of the Hyland varieties $(857 \mathrm{~g} / \mathrm{kg}$ of $\mathrm{DM})$. The carbohydrate fractions among the corn fresh forages were different (Table 3); however, the $\mathrm{CHO}$ factions $(\mathrm{CB}, \mathrm{CC})$ of the Pioneer varieties were similar to those of the Hyland varieties (Table 4). These variations in the concentration and digestion characteristics of the carbohydrates may affect energy intake and animal performance. The CNCPS carbohydrate fractions reveal energy availability to the animal (Lanzas et al., 2007; Tylutki et al., 2008). Hyland Baxxos RR had the highest values for the NSC and CA fractions (C4, $234 \mathrm{~g} / \mathrm{kg}$ of CHO). Hyland SR22 had the highest values for the CB2 $(511 \mathrm{~g} / \mathrm{kg}$ of $\mathrm{CHO})$ and CB3 (309 $\mathrm{g} / \mathrm{kg}$ of $\mathrm{CHO}$ ) fractions (Table 4). The lowest value for the $\mathrm{CC}$ fraction $(80 \mathrm{~g} / \mathrm{kg}$ of $\mathrm{CHO})$ was found in Pioneer 7535R.

The variation in the protein factions among the varieties was high (Table 4). The highest values for the PA, PB3, and PC fractions were observed in Hyland Baxxos RR, which had the lowest true protein and PB2 values. The values of the protein fractions did not differ between the Pioneer (PA: 449, PB2: 375, PB3: 115, and
PC: $63 \mathrm{~g} / \mathrm{kg}$ of $\mathrm{CP}$ ) and Hyland (PA: 460, PB2: 351, PB3: 130, and PC: $61 \mathrm{~g} / \mathrm{kg}$ of $\mathrm{CP})$ varieties $(P=0.45)$. The values for true protein and NPN (50 and $30 \mathrm{~g} / \mathrm{kg}$ ) found in this study were higher than those previously reported in the literature (Hunt et al., 1989; Johnson et al., 1999). The values of the CNCPS fractions reported in corn fresh forage were different from the values of these fractions in corn silage (Lanzas et al., 2007; Tylutki et al., 2008), suggesting that ensiling may increase CP (Lanzas et al., 2007; Tylutki et al., 2008; González et al., 2010).

\section{Rumen Degradation Kinetics of DM and OM}

As presented in Table 5, the highest in situ DM degradation rate $\left(\mathrm{K}_{\mathrm{d}}, 4.5 \% / \mathrm{h}\right)$ was observed in Pioneer 7213R and the lowest rate in Hyland Baxxos RR $(3.0 \% / \mathrm{h} ; P<0.05)$. The soluble fractions $(\mathrm{S})$ of $\mathrm{DM}$ were significantly different between Hyland SR22 and Pioneer 7213R. Hyland Baxxos RR had the highest value for the rumen degradable DM fraction (52\%), and Pioneer 7535R had the lowest value (44\%). The effectively degraded feed DM was found to be high in Pioneer 7535R and low in Hyland Baxxos RR. On average, the Pioneer varieties had higher values than the Hyland varieties for degradation rate $(4.03 \% / \mathrm{h}), \mathrm{U}$ fraction (30.9\%), and effectively degraded DM (405 g/ $\mathrm{kg}$ ). González et al. (2010) reported similar $\mathrm{K}_{\mathrm{d}}$ values (3 to $4 \% / \mathrm{h}$ ) to those of the present study; however, the previous work also observed a higher effective degradability value $(60 \%)$ and a lower undegraded fraction 
Table 4. Differences in carbohydrate and protein subfraction profiles using the Cornell Net Carbohydrate and Protein System (CNCPS): Comparison among the cool-season corn forage varieties ${ }^{1}$

\begin{tabular}{|c|c|c|c|c|c|c|c|c|}
\hline \multirow[b]{2}{*}{ Item } & \multicolumn{3}{|c|}{ Pioneer } & \multicolumn{3}{|c|}{ Hyland } & \multirow[b]{2}{*}{ SEM } & \multirow{2}{*}{$\begin{array}{c}\text { Contrast } \\
(P \text {-value }) \\
\text { Pioneer vs } \\
\text { Hyland }\end{array}$} \\
\hline & $\begin{array}{l}7443 \mathrm{R} \\
(\mathrm{n}=4)\end{array}$ & $\begin{array}{l}\mathrm{P} 7213 \mathrm{R} \\
(\mathrm{n}=4)\end{array}$ & $\begin{array}{l}7535 \mathrm{R} \\
(\mathrm{n}=4)\end{array}$ & $\begin{array}{l}\text { Baxxos RR } \\
(\mathrm{n}=4)\end{array}$ & $\begin{array}{l}\text { SR22 } \\
(\mathrm{n}=4)\end{array}$ & $\begin{array}{l}\text { SR06 } \\
(\mathrm{n}=4)\end{array}$ & & \\
\hline \multicolumn{9}{|c|}{$\begin{array}{l}\text { Carbohydrate fraction }^{2} \\
(\mathrm{~g} / \mathrm{kg} \text { of } \mathrm{CHO})\end{array}$} \\
\hline $\mathrm{CA}$ & $230.93^{\mathrm{c}}$ & $237.02^{\text {bc }}$ & $252.02^{\mathrm{b}}$ & $285.65^{\mathrm{a}}$ & $268.91^{\mathrm{a}}$ & $238.67^{\text {bc }}$ & 6.73 & 0.007 \\
\hline $\mathrm{CA} 4$ & $72.20^{\mathrm{c}}$ & $65.95^{\mathrm{c}}$ & $135.20^{\mathrm{b}}$ & $233.58^{\mathrm{a}}$ & $202.43^{\mathrm{a}}$ & $48.84^{\mathrm{c}}$ & 1.37 & 0.02 \\
\hline CB3 & $283.33^{\mathrm{a}}$ & $274.03^{\mathrm{a}}$ & $271.62^{\mathrm{a}}$ & $205.98^{\mathrm{b}}$ & $309.27^{\mathrm{a}}$ & $281.66^{\mathrm{a}}$ & 12.88 & 0.52 \\
\hline $\mathrm{CC}$ & $87.32^{\mathrm{ab}}$ & $81.78^{\mathrm{b}}$ & $79.76^{\mathrm{b}}$ & $100.99^{\mathrm{a}}$ & $98.23^{\mathrm{a}}$ & $91.10^{\mathrm{ab}}$ & 4.62 & 0.001 \\
\hline \multicolumn{9}{|l|}{ True protein } \\
\hline $\mathrm{TP}(\mathrm{g} / \mathrm{kg}$ of $\mathrm{CP})$ & $511.56^{\mathrm{a}}$ & $488.80^{\mathrm{ab}}$ & $466.67^{\mathrm{b}}$ & $421.28^{\mathrm{c}}$ & $505.29^{\mathrm{ab}}$ & $517.49^{\mathrm{a}}$ & 13.43 & 0.66 \\
\hline \multicolumn{9}{|c|}{ Protein fraction $^{3}(\mathrm{~g} / \mathrm{kg}$ of $\mathrm{CP})$} \\
\hline PA & $424.65^{\mathrm{c}}$ & $453.78^{\mathrm{bc}}$ & $466.88^{\mathrm{b}}$ & $511.35^{\mathrm{a}}$ & $444.44^{\mathrm{bc}}$ & $424.62^{\mathrm{c}}$ & 11.94 & 0.45 \\
\hline PB1 & $\mathrm{ND}^{4}$ & ND & ND & ND & ND & ND & & \\
\hline
\end{tabular}

\footnotetext{
${ }^{\mathrm{a}-\mathrm{d}}$ Values in a row with different letters are statistically different at $P<0.05$ by Tukey comparison.

${ }^{1}$ Corn varieties were from Pioneer Hi-Bred International Inc. (Johnston, IA) and Hyland Seeds (Blenheim, ON, Canada).

${ }^{2}$ Carbohydrate subfractions using CNCPS: $\mathrm{CA}=$ sugars/fast degradable; $\mathrm{CA} 1=\mathrm{CHO}$ A1 fraction (acetate + propionate + butyrate); $\mathrm{CA} 2=$ CHO A2 fraction (lactate); CA3 = CHO A3 fraction (other organics); CA4 = CHO A4 fraction (sugars); CB1 = medium degradable/starch, pectin, and so on; $\mathrm{CB} 2=$ useful fiber/useful cell wall/slow degradable; CB3 = degradable NDF; CC = nonuseful fiber/nonuseful cell wall fraction/lignin.

${ }^{3}$ Protein subfractions using CNCPS: PA = fraction of CP that is instantaneously solubilized at time zero; PB1 = fraction of CP that is soluble in borate-phosphate buffer and precipitated with TCA; PB2 = calculated as total CP minus sum of fractions PA, PB1, PB3, and PC; PB3 = calculated as the difference between the portions of total $\mathrm{CP}$ covered by NDF and ADF; $\mathrm{PC}=$ fraction of $\mathrm{CP}$ recovered with $\mathrm{ADF}$ and considered undegradable; $\mathrm{TP}=$ true protein $($ total $\mathrm{CP})$.

${ }^{4} \mathrm{ND}=$ not detectable.
}

value (15\%; González et al., 2010). The degradability values of fresh corn and silage from whole corn plants, as previously reported by rumen DM degradability kinetics, were similar to our values for the new corn varieties (Jurjanz and Monteils, 2005). Rumen OM was degraded similarly to DM (Table 4); however, the descending order of the varieties for the soluble fraction value was Hyland SR22, Pioneer 7443R, Pioneer 77535R, Hyland Baxxos RR, and Hyland SR06 (Table 4; $P<0.05$ ). Additionally, Pioneer 7535R had the highest effectively degraded feed $\mathrm{OM}$ value $(385 \mathrm{~g} / \mathrm{kg}$ of DM; $P<0.05)$. Furthermore, Pioneer 7535R exhibited significantly higher trending values for the soluble $(22 \%)$ and degradable $(46 \%)$ fractions of OM $(P<0.1$; Table 4). In comparison, the Pioneer and Hyland varieties had the following OM degradability kinetics: $\mathrm{K}_{\mathrm{d}}$ : 4.3 versus $3.3 \% / \mathrm{h}$; S: 20.5 versus $21.5 \%$; D: 50.4 versus $51.1 \%$; U: 29.8 versus $27.4 \%$; and effectively degraded OM: 380 versus $369 \mathrm{~g} / \mathrm{kg}$ of DM. These values indicate that the Pioneer varieties were faster in degradation. The OM degradability of corn fresh forage is similar to that of grass and other forages, such as oat and barley (Van Vuuren et al., 1991; Abeysekara, 2004; Jančík et al., 2009).

\section{Rumen Degradation Kinetics of NDF}

We found no significant differences $(P>0.05)$ in rumen in situ degradation kinetics of the new corn fresh forages, with the exception of rumen undegraded NDF (Table 5). On average, many of the NDF degradability kinetic parameters (S 5.6\%, D 54.8\%, and U 39.5\%) were similar between the Pioneer and Hyland varieties. However, the $\mathrm{K}_{\mathrm{d}}$ and effectively degraded NDF values were significantly different between the varieties (4.6 vs. $4.2 \% / \mathrm{h}$ and 124 vs. $118 \mathrm{~g} / \mathrm{kg}$, respectively, $P<0.05)$. Jurjanz and Monteils (2005) reported faster rumen degradability kinetics for similar forages (2 vs. $5 \% / \mathrm{h}$ ); however, the S, D, and U fraction values were similar across both studies. The typical rumen degradability kinetics reported by Zanton and Heinrichs (2009) in a critical analysis of degradation models (Zanton and Heinrichs, 2009) were similar to our present values $\left(K_{d}\right.$ $=3, \mathrm{~S}=8$, and $\mathrm{D}=60$ ).

\section{Rumen Degradation Kinetics of Starch}

The starch in situ rumen degradability kinetics differed significantly $(P<0.05)$ among the corn fresh 
Table 5. Differences in in situ rumen degradation kinetics of DM, OM, NDF, and starch: Comparison among the newly developed cool-season corn forage varieties ${ }^{1}$

\begin{tabular}{|c|c|c|c|c|c|c|c|c|}
\hline \multirow[b]{2}{*}{ Item $^{2}$} & \multicolumn{3}{|c|}{ Pioneer } & \multicolumn{3}{|c|}{ Hyland } & \multirow[b]{2}{*}{ SEM } & \multirow{2}{*}{$\begin{array}{c}\text { Contrast } \\
(P \text {-value }) \\
\text { Pioneer vs. } \\
\text { Hyland }\end{array}$} \\
\hline & $7443 \mathrm{R}$ & $7213 \mathrm{R}$ & $7535 \mathrm{R}$ & Baxxos RR & SR22 & SR06 & & \\
\hline \multicolumn{9}{|l|}{ In situ DM rumen degradation kinetics } \\
\hline $\mathrm{K}_{\mathrm{d}}(\% / \mathrm{h})$ & 3.40 & 4.54 & 4.19 & 3.01 & 3.28 & 3.74 & 0.59 & 0.15 \\
\hline $\mathrm{T}_{0}(\mathrm{~h})$ & 0.0 & 0.0 & 0.0 & 0.0 & 0.0 & 0.0 & 0.00 & - \\
\hline $\mathrm{S}(\%)$ & $23.58^{\mathrm{ab}}$ & $18.86^{\mathrm{b}}$ & $22.83^{\mathrm{ab}}$ & $22.51^{\mathrm{ab}}$ & $25.32^{\mathrm{a}}$ & $20.71^{\mathrm{ab}}$ & 1.68 & 0.48 \\
\hline $\mathrm{D}(\%)$ & 47.01 & 50.60 & 44.45 & 52.14 & 46.11 & 50.06 & 2.73 & 0.37 \\
\hline $\mathrm{U}(\%)$ & 29.40 & 30.54 & 32.72 & 25.34 & 28.56 & 29.23 & 2.72 & 0.15 \\
\hline Rumen undegraded DM (g/kg of DM) & 597.68 & 597.18 & 589.62 & 611.23 & 593.06 & 604.22 & 9.33 & 0.29 \\
\hline Effectively degraded DM (g/kg of DM) & 402.32 & 402.83 & 410.38 & 388.77 & 406.94 & 395.84 & 9.33 & 0.29 \\
\hline \multicolumn{9}{|l|}{ In situ OM rumen degradation kinetics } \\
\hline $\mathrm{K}_{\mathrm{d}}(\% / \mathrm{h})$ & 3.41 & 4.57 & 4.12 & 2.99 & 3.28 & 3.69 & 0.58 & 0.14 \\
\hline $\mathrm{T}_{0}(\mathrm{~h})$ & 0.0 & 0.0 & 0.0 & 0.0 & 0.0 & 0.0 & 0.00 & - \\
\hline $\mathrm{S}(\%)$ & $22.51^{\mathrm{a}}$ & $17.26^{\mathrm{b}}$ & $21.74^{\mathrm{ab}}$ & $21.01^{\mathrm{ab}}$ & $23.99^{\mathrm{a}}$ & $19.45^{\mathrm{ab}}$ & 1.62 & 0.52 \\
\hline $\mathrm{D}(\%)$ & 48.29 & 52.41 & $45.88^{*}$ & 53.87 & 47.75 & 51.85 & 2.90 & 0.35 \\
\hline $\mathrm{U}(\%)$ & 29.19 & 30.33 & $32.38^{*}$ & 25.12 & 28.26 & 28.70 & 2.84 & 0.15 \\
\hline Rumen undegraded OM (g/kg of DM) & 638.48 & 640.50 & 632.18 & 653.20 & 633.53 & 643.49 & 9.48 & 0.40 \\
\hline Effectively degraded OM ( $\mathrm{g} / \mathrm{kg}$ of $\mathrm{DM})$ & $377.58^{\mathrm{ab}}$ & $376.77^{\mathrm{ab}}$ & $385.28^{\mathrm{a}}$ & $359.76^{\mathrm{b}}$ & $378.96^{\mathrm{ab}}$ & $366.78^{\mathrm{ab}}$ & 8.54 & 0.11 \\
\hline \multicolumn{9}{|l|}{ In situ NDF rumen degradation kinetics } \\
\hline $\mathrm{K}_{\mathrm{d}}(\% / \mathrm{h})$ & 4.03 & 3.00 & 6.76 & 5.14 & 3.92 & 3.49 & 1.66 & 0.01 \\
\hline $\mathrm{T}_{0}(\mathrm{~h})$ & 6.38 & 4.56 & 2.08 & 2.45 & 1.57 & 4.84 & 2.34 & 0.51 \\
\hline $\mathrm{S}$ (washable, \%) & 8.09 & 4.07 & 4.73 & 7.99 & 3.6 & 5.42 & 3.08 & 0.80 \\
\hline $\mathrm{D}(\%)$ & 52.96 & 63.01 & 48.60 & 51.98 & 59.00 & 53.18 & 8.11 & 0.05 \\
\hline $\mathrm{U}(\%)$ & 38.95 & 32.92 & 46.67 & 40.03 & 37.42 & 41.39 & 6.75 & 0.23 \\
\hline Rumen undegraded NDF (g/kg of DM) & $414.53^{\mathrm{ab}}$ & $414.61^{\mathrm{ab}}$ & $388.53^{\mathrm{b}}$ & $390.39^{\mathrm{b}}$ & $468.84^{\mathrm{a}}$ & $409.94^{\mathrm{ab}}$ & 23.21 & 0.54 \\
\hline Effectively degraded NDF (g/kg of DM) & 124.30 & 98.57 & 147.66 & 137.42 & 117.78 & 100.03 & 20.91 & 0.26 \\
\hline \multicolumn{9}{|l|}{ In situ starch rumen degradation kinetics } \\
\hline $\mathrm{K}_{\mathrm{d}}(\% / \mathrm{h})$ & $28.34^{\mathrm{bc}}$ & $45.24^{\mathrm{b}}$ & $41.20^{\mathrm{bc}}$ & $18.00^{\mathrm{c}}$ & $75.91^{\mathrm{a}}$ & $21.99^{\mathrm{bc}}$ & 8.18 & 0.97 \\
\hline $\mathrm{T}_{0}(\mathrm{~h})$ & 0.0 & 0.0 & 0.0 & 0.0 & 0.0 & 0.0 & 0.0 & - \\
\hline $\mathrm{S}(\%)$ & $45.88^{\mathrm{b}}$ & $37.70^{\mathrm{b}}$ & $42.58^{\mathrm{b}}$ & $34.30^{\mathrm{b}}$ & $70.93^{\mathrm{a}}$ & $30.25^{\mathrm{b}}$ & 5.90 & 0.70 \\
\hline $\mathrm{D}(\%)$ & $49.88^{\mathrm{a}}$ & $57.85^{\mathrm{a}}$ & $52.76^{\mathrm{a}}$ & $63.31^{\mathrm{a}}$ & $27.14^{\mathrm{b}}$ & $66.05^{\mathrm{a}}$ & 5.79 & 0.86 \\
\hline $\mathrm{U}(\%)$ & 4.24 & 4.45 & 4.67 & 2.39 & 1.93 & 3.70 & 1.00 & 0.03 \\
\hline Rumen undegraded starch (g/kg of DM) & $39.31^{\mathrm{ab}}$ & $33.83^{\mathrm{b}}$ & $33.56^{\mathrm{b}}$ & $42.38^{\mathrm{ab}}$ & $11.07^{\mathrm{c}}$ & $50.81^{\mathrm{a}}$ & 5.33 & 0.91 \\
\hline Effectively degraded starch (g/kg of DM) & $217.02^{\mathrm{ab}}$ & $207.33^{\mathrm{ab}}$ & $229.77^{\mathrm{a}}$ & $167.70^{\mathrm{b}}$ & $230.99^{\mathrm{a}}$ & $194.66^{\mathrm{ab}}$ & 18.67 & 0.24 \\
\hline \multicolumn{9}{|l|}{ In situ CP rumen degradation kinetics } \\
\hline $\mathrm{K}_{\mathrm{d}}(\% / \mathrm{h})$ & 2.98 & 4.30 & 4.05 & 2.51 & 4.38 & 2.53 & 0.84 & 0.37 \\
\hline $\mathrm{T}_{0}(\mathrm{~h})$ & 0.0 & 0.0 & 0.0 & 0.0 & 0.0 & 0.0 & 0.0 & - \\
\hline $\mathrm{S}(\%)$ & $18.17^{\mathrm{a}}$ & $10.74^{\mathrm{ab}}$ & $9.10^{\mathrm{b}}$ & $1.30^{\mathrm{c}}$ & $9.72^{\mathrm{b}}$ & $16.86^{\mathrm{ab}}$ & 2.82 & 0.28 \\
\hline $\mathrm{D}(\%)$ & $56.80^{\mathrm{ab}}$ & $63.46^{\mathrm{ab}}$ & $53.94^{\mathrm{b}}$ & $74.41^{\mathrm{a}}$ & $55.94^{\mathrm{ab}}$ & $60.21^{\mathrm{ab}}$ & 6.66 & 0.34 \\
\hline $\mathrm{U}(\%)$ & 25.03 & 25.80 & 36.96 & 24.29 & 34.34 & 22.93 & 6.10 & 0.68 \\
\hline Rumen undegraded CP (g/kg of DM) & $51.35^{\mathrm{b}}$ & $50.94^{\mathrm{b}}$ & $50.12^{\mathrm{b}}$ & $54.09^{\mathrm{b}}$ & $52.83^{\mathrm{b}}$ & $65.43^{\mathrm{a}}$ & 1.61 & 0.004 \\
\hline Effectively degraded $\mathrm{CP}(\mathrm{g} / \mathrm{kg}$ of $\mathrm{DM})$ & $26.22^{\mathrm{b}}$ & $23.09^{\mathrm{b}}$ & $18.79^{\mathrm{c}}$ & $12.87^{\mathrm{d}}$ & $23.14^{\mathrm{b}}$ & $30.52^{\mathrm{a}}$ & 1.45 & 0.84 \\
\hline $\begin{array}{l}{ }^{\mathrm{a}-\mathrm{C}} \text { Values in each row having different letter } \\
{ }^{1} \mathrm{C} \text {. }\end{array}$ & cal & $P<$ & & & & & & \\
\hline${ }^{1}$ Corn varieties were from Pioneer Hi-Bred & $\begin{array}{l}\text { onal In } \\
\text { time }(\mathrm{h}\end{array}$ & on, IA) & 1 Seeds & $\begin{array}{l}\text { I, ON, Ce } \\
\text { solubiliz }\end{array}$ & istis & (n) & , & tion at tim \\
\hline
\end{tabular}


forage varieties (Table 4 ). The highest $K_{d}$ was observed in Hyland SR22, and the lowest rate was observed in Hyland Baxxos RR. The highest S fraction $(70.9 \%)$ was found in Hyland SR22, whereas the lowest S (30.3\%) was found in Hyland SR06. In general, the undegraded fraction (U) was small, but statistically significant differences were observed among the varieties. The average values of the Pioneer and Hyland varieties were similar for $\mathrm{K}_{\mathrm{d}}(38.5 \% / \mathrm{h})$ and $\mathrm{D}(53.1 \%)$. However, the values of S (42.1 vs. $45.2 \%)$ and effectively degraded starch (218 vs. $198 \mathrm{~g} / \mathrm{kg}$ of DM) were significantly different. Two of the Hyland varieties (Baxxos RR and SR22) had rumen degradability kinetics similar to the values $(\mathrm{S}=66$ and $\mathrm{D}=32$ ) previously reported by Jurjanz and Monteils (2005); however, the values of the other varieties were not similar. The disappearance of starch in several previous studies may help to explain the differences among these varieties because starch content and quality are strongly influenced by plant genetic composition (Bal et al., 2000; Mahanna, 2009; Der Bedrosian et al., 2012) and plant maturity.

\section{Rumen Degradation Kinetics of CP}

With the exceptions of $\mathrm{K}_{\mathrm{d}}$ and $\mathrm{U}$, the protein degradability characteristics were significantly different $(P<$ 0.05 ) among the varieties (Table 5 ). Pioneer $7443 \mathrm{R}$ possessed the highest soluble protein fraction among the varieties (S, 18.2\%), whereas Hyland Baxxos RR had the lowest S fraction (1.3\%). However, Hyland Baxxos $\mathrm{RR}$ had the highest degradable fraction (D, 74.4\%), whereas Pioneer 7535R had the lowest (53.9\%). Hyland SR06 had the highest effectively degraded $\mathrm{CP}$ value $(30.5 \mathrm{~g} / \mathrm{kg}$ of DM), and Hyland Baxxos RR had the lowest value $(12.9 \mathrm{~g} / \mathrm{kg}$ of $\mathrm{DM})$. The $\mathrm{CP}$ degradability kinetics differed between the Pioneer and Hyland varieties $\left(\mathrm{K}_{\mathrm{d}}: 3.8\right.$ vs. $3.1 \% / \mathrm{h}$; S: 12.7 vs. $9.3 \%$; D: 58.1 vs. 63.5\%; U: 29.3 vs. $27.2 \%$; and EDCP: 22.7 vs. $22.2 \mathrm{~g} /$ $\mathrm{kg})$. These $\mathrm{CP}$ degradation kinetics were not in agreement with those of previous recent work $\left(\mathrm{K}_{\mathrm{d}}=5.8 \% / \mathrm{h}\right.$, $\mathrm{S}=57 \%, \mathrm{D}=28 \%, \mathrm{U}=13 \%$. and $\mathrm{EDCP}=60 \mathrm{~g} / \mathrm{kg}$ of DM) conducted in Europe (González et al., 2010). These differences may be attributable to the variety (Clarica) and climate (Spain) of the previous study (Lauer et al., 2001; Bernard et al., 2004; González et al., 2010).

\section{Metabolic Characteristics of the Proteins and Potential Protein Supply to Dairy Cattle}

The predicted values of the potential protein supply to dairy cattle from the corn fresh forage varieties using the PDI system are shown in Table 6 . The absorbable microbial protein synthesis in the rumen was different among the varieties $(P<0.05)$. The highest and lowest DOM values were found in the Hyland varieties SR06 $(666 \mathrm{~g} / \mathrm{kg}$ of DM) and SR22 $(634 \mathrm{~g} / \mathrm{kg}$ of DM), respectively. A similar pattern was found for FOM and the amount of microbial protein synthesized from the available energy in the rumen. However, the Pioneer and Hyland varieties were not significantly different in terms of synthesized microbial proteins. The Pioneer varieties had an average PDIME value of $57.0 \mathrm{~g} / \mathrm{kg}$ of $\mathrm{DM}$, and the Hyland varieties had an average value of $56.7 \mathrm{~g} / \mathrm{kg}$ of DM. The average value for PDIMN in the Pioneer varieties was $25.8 \mathrm{~g} / \mathrm{kg}$ of DM, and the average value in the Hyland varieties was $28.2 \mathrm{~g} / \mathrm{kg}$ of DM.

The EDCP in the rumen, as predicted with the PDI system, was determined to be highest $(P<0.05)$ in Hyland SR06, in accordance with its higher $\mathrm{CP}$ value. However, TId was not affected by variety. The values obtained in this study for PDIA, PDIN, and PDIE were again highest $(P<0.05)$ for Hyland SR06 (Table 6$)$. The PDIA and PDIN values obtained in this study, except those for Hyland SR06, are in agreement with previous findings for corn fresh forage (INRA, 2007). The net energy values for milk production (UFL) and for meat production (UFV) were found to be highest for Pioneer 7213R forage (Table 6). The UFV and UFL values obtained in our study for the corn fresh forage were lower than those reported by CIHEAM (1981). The predicted values of the potential truly absorbable protein supply to dairy cattle from the corn fresh forage for the Pioneer and Hyland varieties confirmed the lack of major differences in $\mathrm{CP}$ between these 2 groups (Coors and Lauer, 2001). Intestinally digestible ruminally undegraded feed protein was not different between these varieties (Table 7). Total intestinally digestible feed proteins (TDP) were highest (95.35\% $\mathrm{CP})$ in Hyland SR22 and lowest $(65.83 \% \mathrm{CP})$ in Pioneer 7535R. On average, the Hyland varieties were superior to the Pioneer varieties in both aspects (dRUP: 60.9 vs. $56.2 \%$ RUP and TDP: 78.9 vs. $83.1 \%$ CP). The values for the intestinal digestibility of RUP $(52 \%)$ reported by González et al. (2010) for corn green feed were similar to ours. In González et al. (2010), the TDP values (average $81 \% \mathrm{CP}$ ) were closer to the effective degradability of CP $(86 \% \mathrm{CP})$.

The current results indicate that newly bred coolseason corn varieties grown under Canadian prairie weather conditions have nutrient compositions similar to those of varieties grown in warm weather (Hallada et al., 2008; González et al., 2010; Mahanna, 2011). However, our results confirmed that low CHU access leads to relatively low $\mathrm{CP}$ and SCP values despite the lack of effect on NDF contents. Other corn growth factors, such as soil quality, irrigation, and fertilization (even with barn manure), would improve the nutritional quality of 
Table 6. Metabolic characteristics of protein and potential protein supply to dairy cattle from corn fresh forage using the PDI system: Comparison among the cool-season corn forage varieties

\begin{tabular}{|c|c|c|c|c|c|c|c|c|}
\hline \multirow[b]{2}{*}{ Variable $^{2}$} & \multicolumn{3}{|c|}{ Pioneer } & \multicolumn{3}{|c|}{ Hyland } & \multirow{2}{*}{$\begin{array}{l}\text { SEM } \\
(\mathrm{n}=4)\end{array}$} & \multirow{2}{*}{$\begin{array}{c}\text { Contrast } \\
(P \text {-value }) \\
\text { Pioneer vs } \\
\text { Hyland }\end{array}$} \\
\hline & $7443 \mathrm{R}$ & $7213 \mathrm{R}$ & $7535 \mathrm{R}$ & Baxxos RR & SR22 & SR06 & & \\
\hline \multicolumn{9}{|c|}{$\begin{array}{l}\text { Absorbable microbial protein synthesis in the rumen } \\
(\mathrm{g} / \mathrm{kg} \text { of } \mathrm{DM})\end{array}$} \\
\hline PDIME & $56.7^{\mathrm{ab}}$ & $57.5^{\mathrm{ab}}$ & $56.8^{\mathrm{ab}}$ & $55.9^{\mathrm{ab}}$ & $55.5^{\mathrm{b}}$ & $57.6^{\mathrm{a}}$ & 0.47 & 0.005 \\
\hline PDIMN & $27.5^{\mathrm{b}}$ & $26.0^{\mathrm{bc}}$ & $23.9^{\mathrm{cd}}$ & $22.9^{\mathrm{d}}$ & $26.8^{\mathrm{b}}$ & $35.0^{\mathrm{a}}$ & 0.63 & 0.0001 \\
\hline \multicolumn{9}{|c|}{$\begin{array}{l}\text { Truly absorbable rumen undegraded protein in } \\
\text { small intestine }(\mathrm{g} / \mathrm{kg} \text { of } \mathrm{DM})\end{array}$} \\
\hline PDIA & $19.0^{\mathrm{b}}$ & $18.2^{\mathrm{bcd}}$ & $17.1^{\mathrm{cd}}$ & $16.5^{\mathrm{d}}$ & $18.6^{\mathrm{bc}}$ & $21.8^{\mathrm{a}}$ & 0.39 & 0.0001 \\
\hline PDIN (PDIA + PDIMN) & $46.5^{\mathrm{b}}$ & $44.2^{\mathrm{bc}}$ & $40.9^{\mathrm{cd}}$ & $39.4^{\mathrm{d}}$ & $45.3^{\mathrm{b}}$ & $56.9^{\mathrm{a}}$ & 0.96 & 0.0001 \\
\hline PDIE (PDIA + PDIME) & $75.7^{\mathrm{b}}$ & $75.7^{\mathrm{b}}$ & $73.9^{\mathrm{bc}}$ & $72.4^{\mathrm{c}}$ & $74.0^{\mathrm{bc}}$ & $79.4^{\mathrm{a}}$ & 0.52 & 0.0001 \\
\hline \multicolumn{9}{|l|}{ Degraded protein balance } \\
\hline DPB (PDIN - PDIE) & $-29.2^{\mathrm{b}}$ & $-31.5^{\mathrm{bc}}$ & $-33.0^{\mathrm{c}}$ & $-33.0^{\mathrm{c}}$ & $-28.7^{\mathrm{b}}$ & $-22.6^{\mathrm{a}}$ & 0.83 & 0.0001 \\
\hline \multicolumn{9}{|c|}{ Forage unit for net energy in production ( $\mathrm{g} / \mathrm{kg}$ of $\mathrm{DM})$} \\
\hline UFL & $0.41^{\mathrm{ab}}$ & $0.45^{\mathrm{a}}$ & $0.43^{\mathrm{ab}}$ & $0.43^{\mathrm{ab}}$ & $0.38^{\mathrm{b}}$ & $0.41^{\mathrm{ab}}$ & 0.01 & 0.56 \\
\hline UFV & $0.29^{\mathrm{ab}}$ & $0.33^{\mathrm{a}}$ & $0.32^{\mathrm{ab}}$ & $0.31^{\mathrm{ab}}$ & $0.26^{\mathrm{b}}$ & $0.29^{\mathrm{ab}}$ & 0.01 & 0.46 \\
\hline
\end{tabular}

${ }^{\mathrm{a}-\mathrm{d}}$ Values in each row having different letters are statistically different at $P<0.05$ by Tukey mean comparison.

${ }^{1}$ Corn varieties were from Pioneer Hi-Bred International Inc. (Johnston, IA) and Hyland Seeds (Blenheim, ON, Canada).

${ }^{2} \mathrm{PDIME}=$ amount of microbial protein that could be synthesized from the available energy in the rumen, when degraded $\mathrm{N}$ is not limiting; PDIMN = amount of microbial protein

that could be synthesized in the rumen from the degraded dietary $\mathrm{N}$ when energy is not limiting; PDIA = dietary protein undegraded in the rumen, but truly digestible in the small intestine; PDIN = digestible proteins in the small intestine where $\mathrm{N}$ is the limiting factor for rumen microbial activity; PDIE = digestible proteins in the small intestine where energ is the limiting factor for rumen microbial activity; $\mathrm{DPB}=$ balance between microbial protein synthesis from available rumen degradable CP and potential energy from anaerobic O fermentation in the rumen; UFL $=$ forage unit for the net energy value for milk production; UFV = forage unit for the net energy value for meat production 
Table 7. Differences in estimated intestinal digestibility and total available protein from fresh forage: Comparison of cool-season corn forage varieties ${ }^{1}$

\begin{tabular}{|c|c|c|c|c|c|c|c|c|}
\hline \multirow[b]{2}{*}{ Variable $^{2}$} & \multicolumn{3}{|c|}{ Pioneer } & \multicolumn{3}{|c|}{ Hyland } & \multirow{2}{*}{$\begin{array}{c}\text { SEM } \\
(\mathrm{n}=4)\end{array}$} & \multirow{2}{*}{$\begin{array}{c}\text { Contrast } \\
(P \text {-value }) \\
\text { Pioneer vs } \\
\text { Hyland }\end{array}$} \\
\hline & $7443 \mathrm{R}$ & $7213 \mathrm{R}$ & $7535 \mathrm{R}$ & Baxxos RR & SR22 & SR06 & & \\
\hline $\mathrm{TDP}(\mathrm{g} / \mathrm{kg}$ of $\mathrm{CP})$ & $873.95^{\mathrm{ab}}$ & $833.50^{\mathrm{ab}}$ & $658.25^{\mathrm{b}}$ & $817.90^{\mathrm{ab}}$ & $720.48^{\mathrm{ab}}$ & $953.45^{\mathrm{a}}$ & 87.70 & 0.59 \\
\hline
\end{tabular}

${ }^{\mathrm{a}, \mathrm{b}}$ Values in each row having different letters are statistically different at $P<0.05$ by Tukey mean comparison.

${ }^{1}$ Corn varieties were from Pioneer Hi-Bred International Inc. (Johnston, IA) and Hyland Seeds (Blenheim, ON, Canada).

${ }^{2} \mathrm{dRUP}=$ estimated intestinal digestibility of RUP; TDP $=$ total intestinally digestible feed protein.

silage by enhancing plant growth and maturation (Anderegg and Lichtenstein, 1981; Mahanna, 2010). The nutrient composition of this corn fresh forage contains adequate levels of carbohydrate and protein (Weiss et al., 1992; Taylor and Allen, 2005) for ensiling. The present findings demonstrate that cool corn fresh forage is comparable to other conventional forages in nutrient content and availability to animals (NRC, 2001).

\section{CONCLUSIONS}

Protein molecular structure studies showed that the amide I to amide II ratio ranged from 1.09 to 1.66 and that the $\alpha$-helix to $\beta$-sheet ratio ranged from 0.95 to 1.01 in the new cool-season corn varieties, differences that may be related to nutrient digestion and availability. Energy content significantly differed among the new varieties. We found significant differences in the protein and carbohydrate subfraction profiles and in the ruminal degradation kinetics of $\mathrm{OM}, \mathrm{CP}$, starch, and NDF among the new varieties. The varieties had similar estimated intestinal digestibilities for rumen undegraded CP. The new cool-season corn varieties had different total MP values, ranging from 39 to $57 \mathrm{~g} / \mathrm{kg}$ of DM. A variety effect on the nutritive and digestive properties of corn forage was found in new corn varieties grown in cooler weather. However, the nutrient content, degradability, and digestive characteristics of this corn fresh forage indicated that these varieties are nutritionally adequate as ruminant feed in their fresh forms and are likely also adequate after ensiling. Further study of the molecular structure profiles of cool-season corn in relation to nutrient utilization and availability in dairy cattle is necessary.

\section{ACKNOWLEDGMENTS}

The Chair (PY) research programs have been supported by grants from the Ministry of Agriculture Strategic Research Chair Program, and the Saskatchewan Agricultural Development Fund (ADF). The assistance in corn forage supply by the staff at Canada-Saskatchewan Irrigation Diversification Centre (Outlook, SK, Canada) is gratefully acknowledged.

\section{REFERENCES}

Abeysekara, A. W. A. S. 2004. The nutritional value of oat forage for dairy cows. MS Thesis Dissertation. University of Saskatchewan. Accessed Jan. 17, 2013. http://ecommons.usask.ca/handle/10388/ etd-10312003-170820.

Anderegg, B. N., and E. P. Lichtenstein. 1981. A comparative study of water transpiration and the uptake and metabolism of $\left[{ }^{14} \mathrm{C}\right]$ phorate by C3 and C4 plants. J. Agric. Food Chem. 29:733-738.

AOAC (Association of Official Analytical Chemists). 1990. Official Methods of Analysis. 15th ed. Association of Official Analytical Chemists, Arlington, VA.

Arturo, W. 2003. Corn and capitalism: How a botanical bastard grew to global dominance. University of North Carolina Press, Chapel Hill.

Bal, M. A., R. D. Shaver, K. J. Shinners, J. G. Coors, J. G. Lauer, R. J. Straub, and R. G. Koegel. 2000. Stage of maturity, processing, and hybrid effects on ruminal in situ disappearance of whole-plant corn silage. Anim. Feed Sci. Technol. 86:83-94.

Bernard, J. K., J. W. West, D. S. Trammell, and G. H. Cross. 2004. Influence of corn variety and cutting height on nutritive value of silage fed to lactating dairy cows. J. Dairy Sci. 87:2172-2176.

CIHEAM. 1981. Tableaux de la valeur alimentaire pour les ruminants des fourrages et sous-produits d'origine méditerranéenne. Insitut Agronomique Méditerranéen de Zaragoza, Zaragoza, Spain.

Coors, J. G., and J. G. Lauer. 2001. Silage corn. Pages 347-392 in Specialty Corns. 2nd ed. A. R. Hallauer, ed. CRC Press, Boca Raton, FL.

Der Bedrosian, M. C., K. E. J. Nestor, and L. J. Kung. 2012. The effects of hybrid, maturity, and length of storage on the composition and nutritive value of corn silage. J. Dairy Sci. 95:5115-5126.

Dhanoa, M. S. 1988. On the analysis of Dacron bag data for low degradability feeds. Grass Forage Sci. 43:441-444.

Doiron, K. J., P. Yu, J. J. McKinnon, C. Christensen, and D. A. Christensen. 2009. Heat-induced protein structure and subfractions in relation to protein degradation kinetics and intestinal availability in dairy cattle. J. Dairy Sci. 92:3319-3330.

Fox, D. G., L. O. Tedeschi, T. P. Tylutki, J. B. Russell, M. E. VanAmburgh, L. E. Chase, A. N. Pell, and T. R. Overton. 2004. The Cornell Net Carbohydrate and Protein System model for evaluating herd nutrition and nutrient excretion. Anim. Feed Sci. Technol. 112:29-78.

González, J., J. Faría-Marmol, J. M. Arroyo, C. Centeno, and A. Martínez. 2010. Effects of ensiling on in situ ruminal degradability and intestinal digestibility of corn forage. Arch. Anim. Nutr. 64:204-220.

Gyori, Z. 2010. Corn: Characteristics and quality requirements. Pages 183-209 in Cereal Grains: Assessing and Managing Quality. C. W. 
Wrigley, and I. L. Batey, ed. Food Science, Technology and Nutrition Series. Woodhead Publ., Oxford, UK.

Hallada, C. M., D. A. Sapienza, and D. Taysom. 2008. Effect of length of time ensiled on dry matter, starch and fiber digestibility in whole plant corn silage. J. Dairy Sci. 91(Suppl. 1):30. (Abstr.)

Hatfield, R. D. 1989. Structural polysaccharides in forages and their degradability. Agron. J. 81:39-49.

Hunt, C. W., W. Kezar, and R. Vinande. 1989. Yield, chemical composition, and ruminal fermentability of corn whole plant, ear, and stover as affected by maturity. J. Prod. Agric. 2:357-361.

Huntington, J. A., and D. I. Givens. 1995. The in situ technique for studying the rumen degradation of feeds: A review of the procedure. Nutr. Abstr. Rev. 65:63-93.

INRA. 2007. Alimentation des bovins, ovins et caprins. besoins des animaux - Valeurs des aliments. Ed. Quae. Institut National de Recherche Agronomique, Versailles, France.

Jančík, F., V. Koukolová, P. Kubelková, and B. Čermák. 2009. Effects of grass species on ruminal degradability of silages and prediction of dry matter effective degradability. Czech J. Anim. Sci. $7: 315-323$

Johnson, L., J. H. Harrison, C. Hunt, K. Shinners, C. G. Doggett, and D. Sapienza. 1999. Nutritive value of corn silage as affected by maturity and mechanical processing: A contemporary review. J. Dairy Sci. 82:2813-2825.

Johnson, L. M., J. H. Harrison, D. Davidson, W. C. Mahanna, and K. J. Shinners. 2003. Corn silage management: Effects of hybrid, chop length, and mechanical processing on digestion and energy content. J. Dairy Sci. 86:208-231.

Jurjanz, S., and V. Monteils. 2005. Ruminal degradability of corn forages depending on the processing method employed. Anim. Res. $54: 3-15$.

Kamalak, A., O. Canbolat, Y. Gurbuz, and O. Ozay. 2005. Comparison of in vitro gas production technique with in situ nylon bag technique to estimate dry matter degradation. Czech. J. Anim. Sci. 50:60-67.

Lanzas, C., C. J. Sniffen, S. Seoa, L. O. Tedeschi, and D. G. Fox. 2007. A revised CNCPS feed carbohydrate fractionation scheme for formulating rations for ruminants. Anim. Feed Sci. Technol. $136: 167-190$

Lassiter, C. A., C. F. Huffman, S. T. Dexter, and C. W. Duncan. 1958. Corn versus oat silage as a roughage for dairy cattle. J. Dairy Sci. 41:1282-1285.

Lauer, J. G., J. G. Coors, and P. J. Flannery. 2001. Forage yield and quality of corn cultivars developed in different eras. Crop Sci. 41:1449-1455.

Licitra, G., T. M. Hernandez, and P. J. Van-Soest. 1996. Standardization of procedures for nitrogen fractionation of ruminant feeds. Anim. Feed Sci. Technol. 57:347-358.

Liu, B., J. J. McKinnon, P. Thacker, and P. Yu. 2012. Molecular structure and metabolic characteristics of the proteins and energy in triticale grains and dried distillers grains with solubles for dairy cattle. J. Agric. Food Chem. 60:10064-10074.

Liu, N., and P. Yu. 2010. Using DRIFT molecular spectroscopy with uni- and multi-variate molecular spectral techniques to detect plant protein molecular structure difference among different genotypes of barley. J. Agric. Food Chem. 58:6264-6269.

Mahanna, B. 2009. Digestibility of corn starch revisited. Feedstuffs $81: 32-33$

Mahanna, B. 2010. Growing conditions affect silage quality. Feedstuffs $82: 1-2$.

Mahanna, B. 2011. Corn silage continues to be a moving target. Feedstuffs 83:6-9.

McCleary, B. V., C. C. Gibson, and C. C. Mugford. 1997. Measurements of total starch in cereal products by amyloglucosidase- $\alpha$ amylase method. Collaborative study. J. AOAC Int. 80:571-579.

NRC. 1996. Nutrient Requirements of Beef Cattle. 7th rev. ed. National Academies Press, Washington, DC.
NRC. 2001. Nutrient Requirements of Dairy Cattle. 7th rev. ed. National Academies Press, Washington, DC.

Nocek, J. E., and S. Tamminga. 1991. Site of digestion of starch in the gastrointestinal tract of dairy cows and its effect on milk yield and composition. J. Dairy Sci. 74:3598-3629.

Ørskov, E. R., and I. McDonald. 1979. The estimation of protein degradability in the rumen from incubation measurements weighted according to rate of passage. J. Agric. Sci. 92:499-503.

Robinson, P. H., J. G. Fadel, and S. Tamminga. 1986. Evaluation of mathematical models to describe neutral detergent residue in terms of its susceptibility to degradation in the rumen. Anim. Feed Sci. Technol. 15:249-271.

Samadi, , and P. Yu. 2011. Dry and moist heating-induced changes in protein molecular structure, protein subfraction, and nutrient profiles in soybeans. J. Dairy Sci. 94:6092-6102.

Sniffen, C. J., J. D. O'Connor, P. J. Van-Soest, D. G. Fox, and J. B. Russell. 1992. A net carbohydrate and protein system for evaluating cattle diets: II. Carbohydrate and protein availability. J. Anim. Sci. 70:3562-3577.

Struik, P. C., B. Deinum, and J. M. P. Hoefsloot. 1985. Effects of temperature during different stages of development on growth and digestibility of forage maize (Zea mays L.). Neth. J. Agric. Sci. 33:405-420.

Tamminga, S., W. M. Van Straalen, A. P. J. Subnel, R. G. M. Meijer, A. Steg, C. J. G. Wever, and M. C. Blok. 1994. The Dutch protein evaluation system: The DVE/OEB system. Livest. Prod. Sci. 40:139-155.

Taylor, C. C., and M. S. Allen. 2005. Corn grain endosperm type and brown midrib 3 corn silage: Ruminal fermentation and N partitioning in lactating cows. J. Dairy Sci. 88:1434-1442.

Tylutki, T. P., D. G. Fox, V. M. Durbal, L. O. Tedeschi, J. B. Russell, M. E. Van Amburgh, T. R. Overton, L. E. Chase, and A. N. Pell. 2008. Cornell Net Carbohydrate and Protein System: A model for precision feeding of dairy cattle. Anim. Feed Sci. Technol. 143:174-202

Van Soest, P. J., J. B. Robertson, and B. A. Lewis. 1991. Methods for dietary fiber, neutral detergent fiber, and nonstarch polysaccharides in relation to animal nutrition. J. Dairy Sci. 74:3583-3597.

Van Vuuren, A. M., S. Tamminga, and R. S. Ketelaar. 1991. In sacco degradation of organic matter and crude protein of fresh grass (Lolium perenne) in the rumen of grazing dairy cows. J. Agric. Sci. 116:429-436.

Verité, R., and T. Geay. 1987. Evaluation and implementation of the PDI system in France. Pages 249-261 in Feed Evaluation and Protein Requirement Systems for Ruminants. R. Jarrige, and G. Alderman, ed. ECSC-EEC-EAEC, Brussels, Belgium.

Weiss, W. P., H. R. Conrad, and N. R. St. Pierre. 1992. A theoretically-based model for predicting total digestible nutrient values of forages and concentrates. Anim. Feed Sci. Technol. 39:95-110.

$\mathrm{Yu}, \mathrm{P} .2010$. Plant-based food and feed protein structure changes induced by gene-transformation, heating and bio-ethanol processing: A novel synchrotron-based molecular structure and nutrition research program. Mol. Nutr. Food Res. 54:1535-1545.

Yu, P., J. O. Goelema, B. J. Leury, S. Tamminga, and A. R. Egan. 2002. An analysis of the nutritive value of heat processed legume seeds for animal production using the DVE/OEB model: A review. Anim. Feed Sci. Technol. 99:141-176.

Yu, P., J. A. Meier, D. A. Christensen, B. G. Rossnagel, and J. J. McKinnon. 2003. Using the NRC-2001 model and the DVE/OEB system to evaluate nutritive values of Harrington (malting-type) and valier (feed-type) barley for ruminants. Anim. Feed Sci. Technol. 107:45-60.

Zanton, G. I., and A. J. Heinrichs. 2009. Evaluation of modeling procedure for fitting in situ feed degradation profiles. J. Anim. Sci. $87: 2080-2088$. 